Language - Culture - Politics, Vol. 1/2021

ISSN 2450-3576

e-ISSN: $2719-3217$

DOI: $10.54515 /$ lcp.2021.1.259-271

\title{
Siebren Miedema
}

Vrije Universiteit Amsterdam (The Netherlands)

ORCID: 0000-0002-1900-4824

\section{No Sinecure Acting as Public Intellectual in Education \\ Dla intelektualisty, stanowisko w sferze edukacji to nie synekura}

\begin{abstract}
The author has earlier made a plea for educators acting as public intellectuals in society to counteract still influential neo-liberal tendencies in educational policies and practices.

Against emphases on overstretched attention for measurable output and accountability in education, the aim of education in schools is formulated in terms of holistic personhood formation.

Interviewing three educators in different phases of their carrier, it becomes clear that working in academia nowadays it is no sinecure to act as a public intellectual. The author also presents his own experiences in different roles, and makes clear that the instructional niche one is working in could be of utmost importance for really taking that role.

To realize a change, it is, according the author, necessary to stop with too much focus on highly cited publications in academic journals, and on individual researchers instead of on research groups working collectively together in joint research programs and with societal partners.
\end{abstract}

Key words: neo-liberalism, public intellectual, forms of education, holistic personhood formation, experiences of educators. 


\begin{abstract}
Abstrakt
Już wcześniej autor skierował apel w stronę ludzi oświaty, którzy funkcjonują w sferze publicznej jako intelektualiści, aby podjęli działania przeciw istniejącym w dalszym ciągu wpływom neoliberalnych tendencji w edukacyjnej polityce i praktyce.

Zamiast nacisków na kierowanie zbyt wiele uwagi na wymierne osiągnięcia i odpowiedzialność za proces edukacyjny, celem edukacji szkolnej ma stać się ukształtowana holistycznie osobowości.

Przeprowadzając wywiad z trzema nauczycielami akademickimi będącymi w różnych okresach ich kariery zawodowej, stało się jasne, że obecnie praca na uczelni to nie synekura do otwartego działania dla intelektualisty. Autor przedstawia także swoje własne doświadczenia w odgrywaniu różnych ról i ukazuje, że nisza dydaktyczna mogłaby stać się ważnym obszarem do odgrywania takiej roli.

Aby dokonać zmiany konieczne jest, według autora, zrezygnowanie z koncentrowania się na cytowaniu publikacji z czasopism naukowych oraz z badań własnych na rzecz kolektywnych programów badawczych prowadzonych w grupach i we współpracy z partnerami z zewnątrz.
\end{abstract}

Słowa kluczowe: neoliberalizm, intelektualista, formy kształcenia, holistyczne ksztattowanie osobowości, doświadczenia pedagogów.

\title{
A wake-up call
}

In my publication titled "We Need Religious Educators as Public Intellectuals. A Manifesto" (Miedema, 2019), I called on and religious and worldview educators to act as public intellectuals in society. It was meant as a wake-up call to be aware of the still influential neo-liberal rhetoric, politics and practices that are also poisoning and colonizing the educational processes in all schools, be it denominational and public schools.

From a societal and a pedagogical point of view, all schools should be willing - and in my opinion should be obliged - to aim at fostering democratic citizenship education, interreligious or inter-worldview education, and human rights education. So, we need to stimulate the intertwinement of three forms of education: citizenship education, religious or worldview education, and human rights education (Miedema, Bertram-Troost, 2014), that is combining the civic, the sacred and the just in education. Thereby trying to bring about and to promote mutual respect and understanding and to encourage the development of democratic citizenship formation, 
religious or worldview citizenship formation, and human rights formation. (Miedema, 2014b)

Although there has always been and still is a lot of support for these views, especially among religious educators and philosophers of education, there is nevertheless, in my opinion, still an urgent need for a continuing awareness in education towards pedagogy as a necessary counter-voice against the still influential neo-liberal rhetoric, politics and practices. In these practices labormarket orientation and schooling as preparation for the knowledge-based economy are praised as the core aims of education in schools. These neo-liberal voices are not only a threat to education in general, but have at the same time a marginalizing effect on all normative oriented pedagogical approaches such as moral, aesthetic, religious and worldview education.

This tremendous neo-liberal impact in education has to do with the fundamental changes that have taken place since the $90 \mathrm{~s}$ in the educational systems of many countries. Since that time there has been a shift towards far greater external, mostly governmental control over the curriculum, and a far greater emphasis on measurable output and accountability, often related to tight systems of inspection. In this process the purpose of schooling has become increasingly defined in terms of the effective production of a predetermined output, often measured in terms of exam-scores on so-called 'core subjects' such as mathematics and first language. (Biesta, Miedema, 2002; Biesta, 2010; Miedema, 2014b)

This last development of education's orientation, while focusing on Europe and the Europeanization of education on the labor market and education seen as preparation for the knowledge-based economy in terms of employability, flexibility and mobility, has been carefully reconstructed by Peter Schreiner on the basis of documents of the Council of Europe (being the 'conscience' of Europe) and the European Union. Schreiner has shown that notions like 'learning society' and 'knowledge-based economy' cannot mask what he adequately characterizes in Habermasian terms as the colonization of education policy by economic policy imperatives, and the determination of national educational policies on the basis of economical-educational analyses. (Schreiner, 2012)

Even when the notion of edification (Bildung) has recently come back into vogue again by politicians and school administrators this could not mask the fact that in educational policy and practice the basics are still overemphasized to the detriment of the formation of the whole person of the students. This shift towards a one-sided or narrow conception of the aim of schooling makes the question whether there still is or could be more 
space and place for 'education' or 'pedagogy' and its normative aspects in the school an urgent one for those who are in general and from a religious and worldview perspective concerned with the purpose of schooling.

This especially holds for the teachers in the schools who quite often feel that these developments miss the very point of what they think the aim of their work is all about. Our own empirical research on principals of Dutch Christian elementary schools has convincingly shown that their view is fully in line with this kind of criticism. It is clear that the principals are in favor of a concern for the whole person of the students instead of instructional and transmission approaches of a reductionist kind. One of the most important threats the principals experience is the discrepancy between their view on edification (Bildung) as the core and embracing aim of their professional work, and the strong emphasis on instruction, on the basics, and on particular outcomes as such embodied in governmental policies and the way the Inspectorate of Education is operating in assessing their work. (BertramTroost, Miedema, Kom, Ter Avest, 2015)

I notice that the policies and practices in education are fortunately slowly heaving now in more pedagogical directions. This is also due to principals and especially to a young generation of teachers who are organizing themselves on national scales and have a loud and strong pedagogical voice in the public domain. What we, in my view, also really need next to these actors are religious educators acting in different roles and functions as public intellectuals for the benefit of children and youngsters to support them in developing their self-responsible self-determination, their personhood in education and in religious or worldview education. This is necessary, because religious educators are, with a few exceptions, nearly invisible in the public arena so often characterized by clashes of knowledge-politics. (Foucault, 1980)

We probably might think that our arguments for the need of religious and worldview education embedded in a holistic view on personhood formation are self-evident and don't require directing attention to this need of a wider public. However, we definitely need to voice our views in the public square, otherwise other parties will take over our already scarce space, for example the small minority of loud-voiced diehard secularists.

What might also be helpful is to try from a pedagogical-strategical perspective to position new generations of educationalist, philosophers of education and religious educators as gate-watchers in governmental and semigovernmental organizations and institutions to voice from within our 'knowhow' and 'know-that'. 


\section{Public intellectuals}

Following from the statements above, my wake-up call is best to be characterized as a pedagogical, theological and political manifesto. It is a call on religious educators especially in academia, in religious communities and working as civil servants to act as public intellectuals in society at large.

What does it mean to act as public intellectual in society? Intellectuals are the fortunate possessors of a certain amount of cultural capital; with this capital they can play a public role visible for everyone, and always are political issues at stake here. (Nauta, 1992, p. 92) Public intellectuals share two characteristics:

i) They have an obsession for public debates and the corresponding commitment to give account in a very comprehensible way, that is in clear and easy comprehensible language; they are not only writing articles for double-blind refereed and highly cited academic journals and are not obsessed with their Hirsch factor, but are present on radio and TV and in daily newspapers and weeklies;

ii) They are allergic to discrimination and the exclusion of particular groups from taking part in the debates; when such groups are not acquainted with the existing rhetorical traditions the public intellectuals are willing and able to help such groups and are in service to allow them to ask to speak and to speak up. (see also Nauta, 1987, pp. 28-29)

Striving as religious educators to have impact in the public domain as public intellectuals from a strong societal commitment should, in my opinion, always go together with the following of a few very pragmatic rules:

a) Enjoy the public debate and give a comprehensible way account of the insights and knowledge in our discipline;

b) Avoid doing this as a fundamentalistic 'believer', that is in a grim, bitter and pedantic voice, but do this skilful, crystal-clear, and with humour and irony;

c) Ask your opponent in a debate again and again for information in respect to arguments and underpinning of her/his stance, and call them to account on their intellectual integrity. (Miedema, 2007)

What is most threatening and mostly results in not taking the role of a public intellectual? It is overstreched rationality as a means of balance or equilibrium as well as looking for the mid-position, self sought or a position pushed towards by others. The consequence is that voicing a sometimes radical, but at least a clear cut stance in the public square, is avoided. 


\section{My own background in respect to this issue}

My own experience working for more than forty years in academia in the domain of educational foundations (philosophy of education) and religious and worldview education is that acting as a public intelectual is not an easy task. I was strongly influenced in becoming aware of this higly important role and function of academia by my former professor in philosophy of science at Groningen University in the Netherlands, Lolle Nauta. He has not published that much (and would probably have a 'difficult' life in academia today), but with his teaching (courses for master students in which tenured assistant and associate professors of different faculties were attending his lectures), his activities in national political think-tank fora, as well as with his hermeneutical-critical view on academia and society so strongly expressed in his writings, he has had a tremendous influence on his master and $\mathrm{PhD}$ students and in society at large.

I myself have tried to contribute along these lines by playing on different boards at the same time. For example by programming in the past eight years the 2013 conference of the Religious Education Assocation in Boston on the issue of the place of religious education in the public domain. My plea in my Presidential Address was threefold. First, to strive for a legitimate place of religions and worldviews in the public square within the playing field of liberal-democratic societies. Second, to foster the religious or worldview identity formation of students as an inclusive part of the embracing personhood formation for all students in both public and denominational schools, and to strengthen the development of their self-responsible selfdetermination in respect to religions and worldviews. Third, dialogue, encounter and understanding each other should be seen as the devices, instead of policies and practices fostered by anxiety, fear and disrespect. (Nussbaum, 2012) Thus, pedagogues, politicians, administrators, teachers, and leaders of religious and worldview communities and societal organizations, should join forces for the best educational arrangements to let the students' religious and worldview identity formation flourish. This will also be beneficial for the common good, for society broadly speaking. (Miedema, 2014a)

I have tried this also by working since the early 1990s together with the administrative boards of denominational and public schools in the Netherlands, providing them with, as it turned out to be, helpful heuristical models for the development of denominational and public school identity and the formation of personal identity. In respect to school identity of all schools, in my view, three factors determine this identity: the interpretation 
of religious or worldview claims, the conception of the nature of education, and the view of cultural differences as content of education. (Wardekker, Miedema, 2001; Miedema, 2009)

Also by taking as an expert and a member an active role in the recent debates on the justification of the dual Dutch educational system of public and denominational schools in the GreenLeftParty and by writing several essays in different newspapers and magazines.

There are, however, personal and professional reasons not to fulfil this role and there are - last but not least - quite often also systemic, that is institutional and governmental obstacles in respect to academic cultures with a particular view on publishing (for example only publications in high cited journals are counted in the university or faculty 'production' measures), valorisation (usable 'output' that can generate income as return). Quite often the success of a national or international personal research submission for grant money is strongly related to the number of so-called 'high quality' publications.

I was fortunate that during my Deanship in the Faculty of Psychology and Education (2003-2006) I was able to convince the director of research (an excellent researcher in the field of cognitive psychology), that we should not use one format for measuring all departments in the faculty on research performances, but that every department should describe its research context locally, nation wide and globally, thus developing its own parameters. So, in the Department of Theory and Education of my university, Vrije Universiteit Amsterdam, we stated in the mission statement of our research program that we intended to publish in a variety of publication media, national and international academic journals, professional journals, articles in weeklies and newspapers and also books in Dutch and other languages (books were quite often seen as the work of retired scholars). It was our view that in a research group there can be a kind of division of labor. So, acting as a public intellectual should not be perceived as a one-person's business, but could be seen as a task, the responsibility for a research group in toto.

\section{A pilot among three educators}

Currious to learn more about the particular experiences of a few educators positioned in academia, I did a pilot study. In this pilot I focussed on three colleagues in respect to their view on educators acting as public intellctuals and their self-reflection on this issue. These three educators are in different phases of their academic carrier. Two women and one man, and their ages are respectively 38 (A), 69 (B) and 56 (C). In this pilot I inte- 
rviewed them by phone and in advance I had sent them some questions and the chapter that was published in 2019. On the basis of these interviews I will draw some conclusions and plan further research with an extended selection of academics in education and a with a strong international representation.

In general: All three interviewees are convinced that it is important for the field of education and religious education that educators should act as public intellectuals in different media (radio, tv, newspaper and weeklies). The voice of our discipline need to be heard in the public square, next to other voices. (B) also pointed to the serious gap between academic insights and political decision making and the need to bridge that gap.

Their own role: In respect to their own role in academia the picture is more nuanced.

(A) is characterizing herself indeed as public intellctual. She publishes every year at least 1 or 2 newspaper articles. Till now she did not take the initiative for these publications herself, but was always invited by newspaper journalists. Trying to get newspaper articles published in newspapers with a zero of low level of attention for religious education, is very difficult. She uses the helpful input on these from communication experts outside the university. She is publishing widely, thus in national and international academic journals, in academic readers and in professional journals as well as reports for a wider audience interested in religious education.

For her the impact of particular contributions is most important and she is not convinced that newspaper articles are always the most effective way. What is for instance the surplus value of publishing 2 articles in newspapers compared to for example. participation in a professionalisation program for practicing imams on socialization of youngsters in schools? For her, societal service should be interpreted as a form of acting as public intellectual too.

(B) should not immediate label her contributions as the work of a public intellectual. "That is not what I'm doing, and the notion of public intellectual doesn't fit me at all!". She has published only very few newspaper articles and has stopped trying to do this. The reason is that she has very consciously submitted her articles to newspapers that do not publish much related to religion and worldview isues and education and too often the article was rejected without getting clear reasons. "That is waisting my time." It is important for her to share on a regular basis also her theoretical and empirical insights in a variety of professional journals (and there she is often critically challenging the readers and inviting them to react, but unfortunately without success) and in books written for a larger audience than only religious educators per se (academics, teachers, administrators). Her focus is primarily on the professionals in the schools. 
(C) points to the importance of the input of religious educators in respect to the descriptive and normative input in the public domain regarding education and religion in a multicultural society, thus "contributing to a better together". He has not focused on newspapers, weeklies or tv and radio yet. So, he is not that offensive in the public domain, but he is very active on his website hoping to attract attention of a larger audience than just religious educators. By means of intra-church contributions he is presenting theoretical and empirical insights showing aspects of the lifeworld of young people within and outside the church. Taking part in regional encounters where religion/churches and society meet each other on a regular basis, he is representing academia in wider circles in the hope to contribute to more and better understanding regarding religions/worldviews and education.

In terms of systemic hindrances, all three mention here the publish or perish academic focus on output that is still mainstream in academia, although there are some first signs that in this respect academia is really in transition. For (B) these restrictions are less important seen the phase of her academic carrier; she experiences optimal freedom of choice. According to (A), publishing in newspapers and professional journals is allowed, although not stimulated, as long as she publishes enough in international academic journals, and if her valorisation activities (e.g. external in-service training) yield cash value. $(\mathrm{C})$ points to the great pressure on highly cited publications, teaching duties and intra-faculty or intra-university administration. All this hardly leaves any time for public intellectual activities.

In respect to group and/versus individuals, both $(\mathrm{B})$ and $(\mathrm{C})$ are in favour of a collective or community of inquiry of religious educators working together on particular problems or issues and with different roles in terms of presenting and representing. So, beyond a too individualistic focus the group should be perceived as the core entity. In such a constellation hopefully some colleagues are very competent in writing newspaper articles or have affinity with tv, radio or digital media. This presupposes a strong collegiality among the members of the group and of course a different reward system in an organization.

\section{Some conclusions and further insights}

That educators act as public intellectuals in society at large is important for the three educators, because the voice of educators in general and also religious educators need to be heard next to and in dialogue with other voices. This is also necessary in bridging the existing gap between knowledge, 
insights in theory and based on empirical research, experiences from practices and the decision-making processes of politicians and administrators.

Reflecting on their own activities, it is interesting that they also extend the connotation and denotation of the concept 'public intellectual' and show some of the weighting out choices they make between different activities they also label under the notion of 'public intellectual'. They mention for example societal services, book publications explictly focusing on a broad readership, launching a reli-website, valorizing academic insights in church communities, and taking part in regional encounters were church and society meet.

They notice that there are two main barriers for acting as public intellectual. The first one has to do with the fact that the focus in academia is still too much on output in international, highly cited academic journals. There are, in my view, some clear causes for this state of the art. The life-world of religious and worldview educational practices have become too much of a theoretical or virtual entity in stead of a context sui generis seriously taken into account in the academic practices of research. The academic practices have become more and more a reality in its own right and are market-driven by the New $\mathrm{Pu}-$ blic Management ideology. An ideology characterized in academia by a narrow focus on gaining grants, on highly cited journal publications resulting in high $\mathrm{H}$-scores for individual researchers, and for juniors directed on tenured positions and for seniors especially on well paid positions (sometimes adequately characterized as 'cognitive capitalism'). (Schinkel, 2015)

The second barrier, closely related to the first one, is the exclusive focus in academia on individual researchers. What is needed, in stead in my opinion, is a focus on research groups working collectively together within a joint research program. This could be a program in a university context, but also in national and transnational research programs oriented to particular problems to be solved or challenges to be dealt with. From a Science-inTransition-Approach (Dijstelbloem, Huisman, Mijnhardt, Miedema, 2013; Benedictus, Miedema, 2016) researchers should work closely together with relevant societal partners on a regional, national, international or global scale in the context of discovery, the context of justification and the context of use or application. With an emphasis on quality (reliability, comprehensibility) and relevancy (validity, transferability, valorization) the context of use or the valorization of the results should no longer be seen as a by-product of academic research practices but as a core aspect. (Miedema, 2021a; 2021b; see in the same spirit also Aldridge, Biesta, Filippakou, Wainwright, 2018) 


\section{Bibliography}

Aldridge, D., Biesta, G., Filippakou, O., Wainwright, E. (2018). "Why the nature of educational research should remain contested: A statement from the new editors of the 'British Educational Research Journal'". In: British Educational Research Journal, vol. 44 (1).

Benedictus, R., and F. Miedema (2016). "Fewer numbers, better science". In: Nature, 538, 27 October.

Bertram-Troost, G. D., Miedema, S., Kom, C., Ter Avest, I. (2015). "A Catalogue of Dutch Protestant Primary Schools in the Secular Age: Empirical Results". In: Religion E3 Education, vol. 42 (2).

Biesta, G. J. J. (2010). Good Education in an Age of Measurement. Ethics, Politics, Democracy. Boulder/London: Paradigm Publishers.

Biesta, G. J. J., Miedema, S. (2002). "Instruction or pedagogy? The Need for a Transformative Conception of Education". In: Teaching and Teacher Education. An International Journal of Research and Studies, vol. 18.

Blomberg, D., Lambert, I. (eds.) (1998). Renewing the Mind in Learning. Sydney: Centre for the Study of Australian Christianity.

Dijstelbloem, Huisman, H. F., Mijnhardt, W., Miedema, F. (2013). Science in Transition. Why Science does not work as it should and what to do about it. Available at. http://www.scienceintransition.nl/english, (01.09.2021)

Foucault, M. (1980). Power/Knowledge. Selected Interviews and Other Writings. New York: Pantheon Books.

Miedema, S. (2007). Over de zogenoemde teloorgang van het onderwijs en de stem van pedagogen in het publieke debat [On the so-called demise of schooling and the voice of pedagogues in the public debate]. In: H. Amsing, N. Bakker, P. Schreuder, G. Timmerman, J. J. H. Dekker (eds.). Over pedagogische kwaliteit. Historische en theoretische perspectieven op goed onderwijs en goede opvoeding [On pedagogical quality. Historical and theoretical perspectives on good education and good pedagogy]. Amsterdam: SWP.

Miedema, S. (2014a). "'Coming Out Religiously!' Religion, the Public Sphere, and Religious Identity Formation". In: Religious Education, vol. 109 (4).

Miedema, S. (2014b). "From Religious Education to Worldview Education and Beyond: The Strength of a Transformative Pedagogical Paradigm". In: Journal for the Study of Religion, vol. 27.

Miedema, S. (2019). We Need Religious Educators as Public Intellectuals. A Manifesto. In: M. L. Pirner, J. Lähnemann, W. Haußmann and 
S. Schwarz, (eds.). Public Theology and Education. Dordrecht/Heidelberg/London/New York: Springer/Routledge.

Miedema, S. (2021a). "On relevant knowledge and valorization in religious and worldview education". In: Zeitschrift für Pädagogik und Theologie, vol. 73 (1).

Miedema, S. (2021b). Strengthening the links between academia, lifeworld and politics in religious and worldview education. In: F. Schweitzer \& P. Schreiner (eds.). International Knowledge Transfer in Religious Education. Münster/New York: Waxmann.

Miedema, S., Bertram-Troost, G. D. (2014). "Reconciling the Civic, the Sacred and the Just in Critical-Pragmatic Education". In: Religious Education, vol. 109 (1).

Nauta, L. W. (1987). De factor van de kleine c. Essays over culturele armoede en politieke cultuur [The factor of the small c. Essays on cultural poverty and political culture]. Amsterdam: Van Gennep.

Nauta, L. W. (1992). Intellectuelen met en zonder democratie [Intellectuals with and without democracy]. In: L. W. Nauta and G. H. de Vries (eds.). De rol van de intellectueel. Een discussie over distantie en betrokkenheid [The role of the intellectual. A debate on distantiation and involvement]. Amsterdam: Van Gennep.

Nussbaum, M.C. (2012). The new religious intolerance. Overcoming the politics of fear in an anxious age. Cambridge, MA/London, England: The Belknap Press of Harvard University Press.

Schinkel, W. (2015). "Kennis is markt. De universiteit in het cognitief kapitalisme [Knowledge is market. The university in cognitive capitalism]". In: De Groene Amsterdammer, 139, March 25.

Schreiner, P. (2012). Religion im Kontext einer Europäisierung von Bildung. Eine Rekonstrucktion europäischer Diskurse und Entwicklungen aus protestantischer Perspektive. [Religion in the Context of a Europeanization of Edification. A Reconstruction of European Discourses and Developments from a Protestant Perspective.] Münster/New York/München/Berlin: Waxmann.

Wardekker, W. L., Miedema, S. (2001). "Denominational school identity and the formation of personal identity". In: Religious Education, vol. 96 (1).

Correspondence concerning this paper should be addressed to Dr. Siebren Miedema-Emeritus Professor in Religious Education in the Faculty of Theology and Religion and Emeritus Professor in Educational Foundations in 
the Faculty of Behavioural and Movement Sciences at the Vrije Universiteit Amsterdam, the Netherlands. He has published numerous books, chapters and articles both in academic and professional journals and newspaper articles and gave numerous lectures all over the globe.

E-mail: s.miedema@vu.nl 